\title{
The comparative method in European Courts: A comparison between the CJEU and ECtHR?
}

\author{
SABINE GLESS and JEANNINE MARTIN
}

\section{Introduction}

If European Courts were 'playing house' in the traditional, stereotypical way, the European Court of Human Rights (ECtHR) would take the role of the rather soft-spoken, but on certain points firm, 'Mommy'. Meanwhile, the Court of Justice of the European Union (CJEU) would play the bold, sometimes gruff, and occasionally audaciously acting 'Daddy' - with both taking care of the well-being of their children, i.e. the Member States, including human rights issues.

At play, both courts use a comparative method to justify their decisions.

How do they proceed? And why is there - as claimed at the very beginning - a difference in the application of the choice of 'comparative method'?

\section{Comparative Method - General Remarks}

First and foremost, the question to be answered is: What comparative method is applied by the European Courts?

The comparison of laws and legal systems has a long tradition among scholars, who compare their home laws with those of other national legal systems. ${ }^{1}$ The comparative method applied by courts, however, has been slightly different due to the disparate purpose. Courts are rather inclined to 'borrowing' legal discourse from another country and thus may join the "global community of courts". 2 The European Courts also use this method of choosing and enhancing when comparing the laws of their respective Member

Sabine Gless, Professor of criminal and criminal procedural law at the Faculty of Law, University of Basel and Jeannine Martin, Faculty of Law, University of Basel.

1 Cf. Viola Heutger and Eltjo Schrage, "Legal history and comparative law", in Elgar Encyclopedia of Comparative Law (ed. Jan M. Smits), Edward Elgar 2012, p. 512; Esin Örücü, "Developing Comparative Law”, in Comparative Law - A Handbook (eds. Esin Örücü and David Nelken), Hart Publishing 2007, p. 43.

2 See for instance Anne-Marie Slaughter, "A Global Community of Courts", 44 Harvard International Law Journal 191 (2003). 
States. Especially when discussing issues connected to human rights, there may be a real risk that the comparison appears highly selective and even non-transparent. The reasons for this have been accurately articulated by Christoph McCrudden:

\footnotetext{
"Human rights practice is often driven by a strong moral or ethical dimension (...). For the human rights advocate the role of comparison is that of persuasion to an essentially moral position. Lawyers in the human rights context often use comparison to legitimate their argument that a particular interpretation of an existing human rights norm should be adopted, or as part of the process of generating further norms. The use of comparison as part of the process of persuasion not infrequently gives rise to highly selective, often rather simplistic comparative arguments."3
}

To address the problems that arise when comparing the laws of different States, many approaches have been developed for 'comparative law' and a vast number of scholars have used and refined them. ${ }^{4}$ Nevertheless, it is impossible to give a clear-cut definition - or even a roughly adequate survey - in a short introduction.

If one wants to sketch a comtemporary characterization of work in the field of comparative law today, one has to resort to extremely general requirements for a comparative method. For the purposes of this article, we will emphasize two important points:

1. Comparative work can only be done with a clear objective in mind;

2. The comparison must follow a well-defined process, during which the various obstacles to legal comparison must be identified and addressed (such as sources of law considered, language problems, cultural contexts, impact of practice of law, etc)..$^{5}$ The process of comparison represents the most complicated and most crucial aspect of comparative law and the - not yet achieved - ideal would be a set of binding, broad, yet rigid, rules governing this process.

Because of the methodological flaws, there is no such thing as 'the comparative method' (even if the title of this article suggests otherwise) and - perhaps even more importantly - the validity of comparative work is, by and large, in the eye of the beholder.

When considering the comparative method of the European Courts against this background, the differences commence with the first element: The objective of comparison and the purpose of the respective comparative method.

The European Court of Human Rights (ECtHR) compares laws and legal systems of its Member States in order to find a consensus on human rights among the European countries that have pledged obedience to the European Convention of Human Rights (ECHR). In this respect, it must establish a 'minimum standard'. In contrast, the Court of

3 Christopher McCrudden, "Judicial Comparativism and Human Rights", in Comparative Law - A Handbook (eds. Esin Örücü and David Nelken), Hart Publishing 2007, pp. 371-397, 376.

4 See for instance Esin Örücü, “Developing Comparative Law”, in Comparative Law - A Handbook (eds. Esin Örücü and David Nelken), Hart Publishing 2007, pp. 43-65, 43 ff. with further references.

$5 \quad$ Esin Örücü (2007), p. 50 f. 
Justice of the European Union (CJEU) compares the national laws and legal systems of its Member States in order to ensure a coherent application of community law throughout the European Union, or rather in all the States that have submitted to the EU. In doing so, it establishes a - sometimes far-reaching - European consensus on EU law.

The differences necessarily continue regarding the second element: The question of how to compare. This will be further elaborated by this article.

But before going into medias res, it is important to note that the disagreement among comparative scholars about their work not only hinders a straightforward scientific discussion, but may also ultimately create a risk of weakening 'comparative law' as such by placing the jurisprudence in a grey area between the power play and law.

This point, however, will not be further elaborated on. Instead, this article will:

1. take a closer look at the comparative method of the ECtHR

2. look subsequently at the comparative method of the CJEU,

3. sum up the differences and common ground,

4. and conclude with some perspectives.

\section{The Comparative Method in the ECtHR's Case Law - General Remarks}

If one looks at the European Court of Human Rights' comparative method in a nutshell with regard to the approach, we see that, from the beginning, the Strasbourg Court explicitly took its Member States' laws into account, sometimes fairly 'mechanically' or 'arithmetically', but basically 'counting numbers' ${ }^{6}$ of similar laws and rules. Over the years, however, it has come to look more for common substance, and it has also sought common ground beyond national legislation - in international law, for instance, it looks to European Council conventions other than the ECHR. ${ }^{7}$

With regard to the outcome, the ECtHR appears to act rather leniently as long as the Member States abide by a minimum standard, yet takes a stricter stance on certain points. Basically - in its 'Mommy' role - it tries to build a consensus of 'what is right' among

For instance, in ECtHR, Opuz v Turkey, (application 33401/02), judgment of 9.6.2009, paras 87 ff.: 'Comparative Law material' regarding prosecution of domestic violence; ECtHR, Konstantin Markin v. Russia, (application 30078/06), judgment of 22.3.2012, paras. 71-75: Comparative Law material regarding parental leave for men; ECtHR, Van der Heijden v. the Netherland, (application 42857/05), judgment of 3 April 2012, paras. 31-36 on the question whether in criminal proceedings the spouse of the defendant can be compelled to give evidence.

7 ECtHR, Marckx v. Belgium, (application 6833/74), judgment of 13.6.1979, para. 41; Mónika Ambrus, "Comparative Law Method in the Jurisprudence of the European Court of Human Rights in the Light of the Rule of Law”, Erasmus Law Review, Volume 02, Issue 03 (2009), pp. 353-371, 363. 
the contracting parties. In the long run, this non-intrusive method ${ }^{8}$ has developed quite high standards in a very subtle way, and it has managed to create largely self-conscious, well-behaved States.

On closer inspection: How (or rather why) did this 'Mommy' approach develop?

The ECtHR, as the standing court of the ECHR, started its work in 1959 with the objective 'to ensure the observance of the engagement undertaken' ${ }^{9}$ by the Contracting States in relation to the Convention.

\section{1 'Minimum Standard'}

Thus, it first had to define a minimum standard below which no Member State was allowed to fall. ${ }^{10}$ Hence, the search for the lowest common denominator in the area of human rights began, but it then yielded to a Strasbourg benchmark, based on the justice systems of the Member States of the Council of Europe. ${ }^{11}$ The Court has always been clear that bad practice would not lower standards: A strong set of human rights does not allow for a race to the bottom, and the case law on torture is perhaps the most prominent example here. ${ }^{12}$

\section{2 'Margin of Appreciation' Doctrine}

The Strasbourg Court's first and most important approach of setting minimum standards is not only a consequence of its mandate (to ensure observance to the ECHR), but also follows from the Court's prudent self-restraint: The ECtHR respects the Member States' sovereignty, as it also needs their cooperation when it comes to enforcement of the Court's judgments. ${ }^{13}$

From this reasoning, the ECtHR developed the doctrine of 'margin of appreciation'. On the basis of this principle, the Strasbourg Court takes into consideration that the Con-

8 See Y. Shaney, “Toward a General Margin of Appreciation Doctrine in International Law”, 16 EJIL (2006), pp. 907 ff., 908.

$9 \quad$ Art. 19 ECHR.

10 ECtHR, Longin v. Croatia, (application 49268/10), judgment of 6.11.2012, paras. 54 ff.; Art. 6 para. 3 defining the minimum standard of a fair trial in criminal proceedings.

11 Ambrus (2009) p. 356; Dialogue between Judges, 'What are the limits to the evolutive interpretation of the Convention?', European Court of Human Rights, Council of Europe 2011, p. 9; Eva Brems, Human Rights: Universality and Diversity (Martinus Nijhoff Publishers 2001), pp. 360-361.

12 See e.g. ECtHR, Gäfgen v. Germany, (application 22978/05), judgment of 1.6.2010, para. 107 as to the absolute character of the prohibition of torture; ECtHR, Longin v. Croatia, (application 49268/10), judgment of 6.11.2012, paras. 54-62 where the Court sets its own standards as to space to be provided to a detainee with further references; also ECtHR, Stanev v. Bulgaria, (application 36760/06), judgment of 17 January 2012, paras. 206-213 where the Court establishes minimal standards to be complied with in a social care home and found a violation of Art. 3 ECHR despite the fact that all inhabitants were subject to the same conditions and without taking into account the practice of other States in this area. 
vention will be interpreted differently in different Member States: It gives the individual Member States 'elbow room' ${ }^{14}$ (since judges must always take into account the cultural, historical and philosophical differences between Strasbourg and the nation in question).

On the other hand, it is done by a comparative method, which is applied to find a 'majority'. If such comparison of laws is successful and leads to a widely shared common European standard, an individual state's discretion to deviate is limited. Or to use the words of the Court: Where the comparison shows that the "domestic law and practice of the Contracting States reveal a fairly substantial measure of common ground" in a certain area, "a more extensive European supervision corresponds to a less discretionary power of appreciation." 15

Over time, the ECtHR has developed a rich array of instances where Contracting States enjoy a wide margin of appreciation. For example, it is within the States' discretion how they protect mentally disabled people in procedures concerning their right to family life. ${ }^{16}$ Moreover, it is for the national authorities to make the initial assessment as to the existence of a problem of "public interest" warranting measures to be applied in the sphere of exercising the right of property, including deprivation and restitution of property. ${ }^{17}$ The Contracting States further enjoy a wide margin of appreciation in assessing whether and to what extent differences in otherwise similar situations justify different treatment, such as the regulation of retirement pensions of former employees ${ }^{18}$ or treating landowners of bigger and smaller plots of land differently for the purpose of hunting regulations. ${ }^{19}$ The States have broad discretion when assessing the manner in which they allow or prohibit suicide and assisted suicide ${ }^{20}$ and in determining the language taught at public schools. ${ }^{21}$ Or, as a final example, it is for the States to examine, to a certain extent, what is "necessary in a democratic society" when interfering with the freedom of expression. ${ }^{22}$

This 'comparative method' is applied in order to unify. Methodologically speaking, the Court takes a rather 'mechanical' or 'arithmetical' approach to the comparison of

14 Howard Charles Yourouw, The Margin of Appreciation Doctrine in the Dynamics of European Human Rights Jurisprudence, (Kluwer 1996) p. 13.

15 ECHR, Sunday Times v. the United Kingdom, (application 6538/74), judgment of 26.4.1979, para. 59.

16 ECtHR, R.P. and Others v. the United Kingdom, (application 38245/08), judgment of 9.10.2012.

17 ECtHR, Maria Atanasiu and Others v. Romania, (applications 30767/05 and 33800/06), judgment of 12.10.2010.

18 ECtHR, Arras and Others v. Italy, (application 17972/07), judgment of 14.2.2012.

19 ECtHR, Chassagnou and Others v. France, (applications 25088/94, 28331/95 and 28443/95), judgment of 29.4.1999; ECtHR,Chabauty v. France, (application 57412/08), judgment of 4.10.2012.

20 ECtHR, Koch v. Germany, (application 497/09), judgment of 19.7.2012; ECtHR, Haas v. Switzerland, (application 31322/07), judgment of 20.1.2011.

21 ECtHR, Case "Relating to certain aspects of the laws on the use of languages in education in Belgium" v. Belgium (Mertis), (applications 1474/62; 1677/62; 1691/62; 1769/63; 1994/63; 2126/64), judgment of 23.7.1968.

22 ECtHR, Weber v. Switzerland, (application 11034/84), judgment of 22.5.1990. 
laws, but it acknowledges at the same time that the Strasbourg Court should be subsidiary to the protection of human rights in national systems: It leaves the difficult questions to be solved by the democratically elected legislatures of the Contracting Parties. ${ }^{23}$ This is especially important in controversial fields or topics affected by cultural conventions, such as (with regard to criminal justice systems) the criminalization of abortion or marital rape $\left(C v . U K^{24}\right)$, conjugal visits in prisons $\left(X\right.$ and $Y v$. Switzerland $\left.{ }^{25}\right)$ or even the law of evidence (Gäfgen v. Germany ${ }^{26}$ ).

Overall, through the rather soft-spoken words and the flexibility given to States so as to make their own choices, it has been left to national governments to accept and implement certain human rights standards. The method has certainly been an element in the success story of the ECtHR: If one has the freedom to choose and decide for oneself, one is more ready to accept advice rather than receive an order.

However, the effect of the 'margin of appreciation' approach is not without a downside. Notably, it leads to rather ambivalent rulings when a clear-cut human rights scheme is missing.

A prominent example of this dilemma is the prohibition of torture. While the prohibition itself is quite clear, the Court operates in murky waters when evidence is not directly obtained by torture, as was impressively illustrated by the case of Gäfgen v. Germany:

As it is known, Gäfgen had lured a boy into his apartment, killed him and hid the body, but nevertheless demanded a ransom payment from the parents who were unaware that their child was already dead. Following delivery of the ransom, the police arrested Gäfgen as a suspect. During interrogation, the police, acting under the assumption that the victim was still alive, threatened the suspect with considerable suffering if he did not disclose the boy's whereabouts. In this situation, the suspect confessed to the crime and disclosed the whereabouts of the body. The German courts established that the suspect's confession had been extracted under duress and thus would not be admissible as evidence during the ensuing criminal trial, nor would the child's body and/or the tire tracks found at the dumping site be admissible, since they were all obtained as a result of the ill-treatment. However, during the trial, the suspect confessed again, despite having been made aware of his right to remain silent and of the inadmissibility of his earlier confession as evidence. Little has been said in public about the second confession, since it is well known that in German criminal trials, the court deciding on the merits also decides on admissibility of evidence and thus knows all the inadmissible evidence when handing down the judgment.

\footnotetext{
23 Dialogue between Judges (2011) p. 17 and 26.

24 ECtHR, C.R. v. United Kingdom (application 20190/92) judgment of 22.11.1995

25 ECtHR, X. and Y. v. Switzerland, (application 8166/78), decision of 3.10.1978.

26 ECtHR, Gäfgen v. Germany, (application 22978/05), decision of 1.6.2010
} 
The Grand Chamber of the ECtHR held that Gäfgen's rights under Article 3 ECHR were violated. It emphasized that the threat of torture constituted inhuman treatment and made it very clear that no situation can justify an infringement of Article 3. The severity of its position on this matter illustrates that the ECtHR can stand its ground firmly (especially when the law on the books in all Member States is unambiguous).

Nonetheless, the Court's reaction to the claim of an unfair trial because of the evidence was procured under a threat of torture, was something of a soft-spoken sermon: The Grand Chamber turned down the applicant's claim that his right to a fair trial had been violated, by the fact that the evidence obtained as a result of the threat of torture had been declared admissible for use during the criminal trial. A majority vote held that Article 6 ECHR had not been violated, because "contrary to Article 3, Article 6 does not enshrine an absolute right". A "criminal trial's fairness [is] only at stake if it has been shown that the breach of Article 3 had a bearing on the outcome of the proceedings" and, in the present case, the "conviction [was] based exclusively on the new, full confession made by the applicant at the trial" 27 .

The Court's statement that there was an insufficient link between the threat of torture and the conviction, and that "the breach of Article 3 in the investigation proceedings had no bearing on the applicant's confession at the trial", in a way turns a blind eye to the factual situation in the German courtroom, where everybody knew of the earlier confession and the subsequent findings. Not mentioning this fact, and leaving it to the State to sort out the consequences is, to a certain extent, part of the ECtHR's 'margin of appreciation' approach. The Court can decide differently as it did in Jalloh v. Germany, for instance, where it held that "incriminating real evidence - obtained as a result of (...) torture should never be relied on as proof of the victim's guilt." ${ }^{28}$

\section{3 'Practical and Effective' Doctrine and 'Liv- ing Instrument' Approach}

Having drawn attention to the comparative approach based on the margin of appreciation doctrine in building a sturdy, albeit minimum, human rights standard, it must be pointed out that such an approach alone will be ineffective if the long-term objective is to further the protection of human rights rather than merely ensuring rights are not breached. Therefore, the Strasbourg Court has not restricted itself to this cautious comparative method: The ECtHR long ago moved beyond looking for the common denominator. It has developed instruments that go further than a simple comparison of Europe's judicial systems, adopting an evolving interpretation of the Convention.

27 ECtHR, Gäfgen v. Germany, (application 22978/05), decision of 1.6.2010

28 ECtHR, Jalloh v. Germany, (application 54810/00), judgment of 11.7.2006, para. 105. 
In 1968, the Court introduced for the first time the ground-breaking 'practical and effective' doctrine, claiming that rights enshrined in the Convention are not to be theoretical and illusionary, but rather practical and effective. ${ }^{29}$

For example, in Airey v. Ireland ${ }^{30}$ - which is not a criminal case at first sight, yet it bears consequences for defence attorneys - Mrs. Airey wished to obtain a decree of judicial separation from her husband (divorce was illegal in Ireland). She had been unable to find a solicitor willing to act on her behalf due to the absence of legal aid and not being in a financial position to meet the costs involved herself. Legal aid was not available in Ireland for any civil matters, including seeking a judicial separation. ${ }^{31}$ The ECtHR concluded that "Article 6 para. 1 may sometimes compel the State to provide for the assistance of a lawyer when such assistance proves indispensable for an effective access to court." ${ }^{32}$ As a consequence, the Court introduced a right to legal aid in civil matters for certain cases through the 'practical and effective' doctrine, although such a right was not explicitly set out in Article 6 ECHR.

In Scoppola v. Italy, a case about Italy's automatic ban on prisoners' voting rights and a possible breach of Article 3 ECHR, the Strasbourg Court introduced another evolutionary element, the 'living instrument' doctrine:

\footnotetext{
"Since the Convention is first and foremost a system for the protection of human rights, the Court must however have regard to the changing conditions in the respondent State and in the Contracting States in general and respond, for example, to any emerging consensus as to the standards to be achieved." 33
}

In Tyrer v. UK, another prominent case decided in 1978, the complainant (then aged 15) was subjected to corporal punishment by policemen in private, but in the presence of Tyrer's father and a doctor; Tyrer was made to take down his trousers and underpants and bend over a table. Although the Isle of Man argued that this was a well-accepted way of punishing criminals on the Isle, Strasbourg held that "the Court cannot but be influenced by the developments and commonly accepted standards in the penal policy of the member States of the Council of Europe in this field," declaring that according to this new common ground Art. 3 ECHR had been violated. ${ }^{34}$

29 ECtHR, Belgian Linguistic case, paras. 3-4.

30 ECtHR, Airey v. Ireland, (application 6289/73), judgment of 9.10.1979, para. 24.

31 See, mutatis mutandis, the "Belgian Linguistic" case p. 31, paras. 3 in fine and 4;ECtHR, Golder v. the United Kingdom, (application 4451/70), judgment of 21.2.1975, para. 35 in fine; ECtHR, Luedicke, Belkacem and Koç v. Germany, (applications 6210/73, 6877/75 and 7132/75) judgment of 28.11.1978, para. 42; and ECtHR, Marckx v. Belgium, (application 6833/74), judgment of 13.6.1979, para. 31.

32 ECtHR case Airey v. Ireland, para.26.

33 ECtHR, Scoppola v. Italy (No. 2), (application 10249/03), judgment of 17 September 2009, para. 104.

34 ECtHR, Tyrer v. the United Kingdom, (application 5856/72), judgment of 25 April 1978, para. 31; see also Kress v. France [GC], no. 39594/98, § 70, ECHR 2001VI; and ECtHR, Christine Goodwin v. the United King- 
Both evolutionary elements - the 'practical and effective' doctrine and the 'living instrument' doctrine - leave behind the comparative method limited to detecting a common denominator. ${ }^{35}$ They helped developing a new scope for human rights and thereby promote the consensus on protection of fundamental freedoms in Europe. Soon enough, however, this raised criticism and the question on the limits of such extensive interpretation. ${ }^{36}$ Yet, the Court reacted to it by recalling the limitations of such an evolution, stating that the 'living instrument' doctrine:

'... does not, however, mean that to respond to present-day needs, conditions, views or standards the Court can create a new right apart from those recognised by the Convention (...) or that it can whittle down an existing right or create a new "exception" or "justification" which is not expressly recognised in the Convention. ${ }^{37}$

\subsection{Conclusion and Perspectives}

To summarize, we have seen that 'the comparative method' of the Strasbourg Court is the result of interplay between a rather 'arithmetic' comparative approach (i.e. aiming at a common denominator) and more evolutionary elements (i.e. 'practical and effective' or 'living instrument' doctrine). ${ }^{38}$ To achieve this, the Strasbourg Court not only referred to the national laws of the Member States, but also consulted the common spirit of the States reflected in international law. ${ }^{39}$

Where could this Strasbourg comparative method lead to?

Taking the 'practical and effective' doctrine seriously inevitably leads to a theory of positive obligations of the Member States - i.e. duties in order to ensure the exercise of human rights. ${ }^{40}$ We have experienced such a development on the national level. ${ }^{41}$ And the Court has already handed down judgments, which - not surprisingly - rely to a lesser extent on the domestic laws of the Member States, and instead mainly focus on commonly

dom, (application 28957/95), judgment of 11.7.2002, para. 75 .

35 Dialogue between Judges, (2011) p. 7.

36 Ambrus (2009) p. 368-370 with further references; Dialogue between Judges (2011) pp. 9 and 18.

37 ECtHR, Austin and Others v. The United Kingdom, (applications 39692/09, 40713/09 and 41008/09), judgment of 15 March 2012, para. 53.

38 See for instance Scoppola v. Italy, para. 104.

39 See ECtHR, Bayatyan v. Armenia, (application 23459/03), judgment of 7.7.2011, PARA. 102; ALSO SEE ECTHR, Demir and Baykara v. Turkey, (APPLICATION 34503/97), JUDGMENT OF 12.11.2008, PARA. 85.

40 ECtHR, Marckx v. Belgium para. 31; see also Dialogue between Judges (2011), p. 16 - or also Opuz v. Turkey where Turkey violated its obligations under Arts 2, 3 and 14 ECHR, because it did not protect the applicant and her mother adequately from domestic violence. In this landmark decision, the Court held that domestic violence is a form of discrimination that States are required to eliminate and remedy.

${ }_{41}$ See for Switzerland: Jörg P. Müller/Markus Schefer, Grundrechte in der Schweiz - Im Rahmen der Bundesverfassung, der EMRK und der UNO-Pakte, Stämpfli Verlag AG 2008, 4th edition, p. 75; see for Germany: Volker Epping, Grundrechte, Springer 2010, 4th edition, pp. 50- 51, paras. 117-118. 
accepted international law, thus taking the risk of constructing rights not known before in national law. ${ }^{42}$

\section{The Comparative Method in CJEU's Case Law - General Remarks}

In contrast, the Luxembourg Court's comparative method has never taken an arithmetic approach of counting the number of laws at the national level. In a nutshell, with regard to approach:

The Luxemburg Court, being the highest court of the EU, first and foremost ensures compliance with EU law, more or less regardless of national laws. Accordingly, there seems to be no need for a 'comparative method' at all. ${ }^{43}$

However, since EU law was not set up as an all embracing legal system, but rather started in a "piecemeal" manner, built around the various EU competencies, the Luxembourg Court needed national laws to fill in the gaps. For instance, even today, EU statutes refer to general principles common to the law of the Member States when reviewing the legality of EU actions ${ }^{44}$ or when determining damages in lawsuits. ${ }^{45}$

More prominently, and now laid down in Article 6 paragraph 3 TEU, the Luxembourg Court must protect fundamental rights following from "the constitutional traditions common to the Member States". Such rights were not originally foreseen in an EU Charter, nor was there a clear reference to the ECtHR case law as we know it today.

In order to discover the substance of such general principles or "constitutional traditions common to the Member States", the CJEU must apply a comparative method. This explains why judges in Luxembourg look at national legislation at all - but they are looking for inspiration and the spirit of the European people behind such national laws, not for "numbers" like the Strasbourg Court. This is one of the reasons why the comparative approach in Luxembourg is basically a very broad teleological interpretation.

With regard to the outcome, the CJEU is not lenient in any area but demands obedience in order to put EU law into effect. It does not build a consensus among Member States, but ensures that EU law is observed.

Why does "Daddy" act so differently?

The CJEU must adopt another approach when it comes to the comparative method - because the CJEU is not "granting minimum rights", yet is the highest court when it comes to the interpretation of EU Law. As Justice Murray stated, "one of the primary roles

\footnotetext{
$42 \quad$ ECtHR Marckx v. Belgium, para. 41; Ambrus (2009), p. 363.

43 Therefore, the CJEU refers very little to national law; for one of the exceptions, see CJEU joined cases C-7/56 and C-3-7/57, Algera, Cicconardi, Couturaud, Genuardi, and Steichen, [1957].

$44 \quad$ See Art. 263 TEC, see also: T. Tridimas, The General Principles of EU Law (OUP 2006), p. 19.

45 See, for instance, in Art. 340 TEC.
} 
of the Court of Justice is to ensure the coherent and harmonious application of community law throughout the European Union." ${ }^{46}$

\subsection{The CJEU's evaluative approach}

Determined to reach this goal, the CJEU explained from the start ${ }^{47}$ that it is required to apply Community law only, and it is not competent in the field of national laws of the Member States.

Consequently, in its comparative approach, the Luxembourg Court does not analyse national laws or legal systems with the objective of identifying a common denominator, but seeks a synthesis of various national laws. It works with an 'evaluative' approach that refers only to those statutes of relevant national law, which leads to the most appropriate solution of a case in light of EU law.

This was, for instance, illustrated in a case dealing with property rights, Liselotte Hauer v. Land Rheinland-Pfalz, which dealt with the question whether restrictions on the use of property for the production of wine violated the right to property. When evaluating the lawfulness of restrictions on the cultivation of vineyards with the aim of regulating the wine market, the Court simply stated that "all the wine-producing countries of the community have restrictive legislation, albeit of differing severity, concerning the planting of vines, the selection of varieties and the methods of cultivation. In none of the countries concerned are those provisions considered to be incompatible in principle with the regard due to the right to property" ${ }^{48}$ This was a sufficient argument for the Court to allow restrictions on the right to property through Community law. Apparently, the Court considered this the most appropriate solution for the regulation of the wine market in the interest of all Member States.

\subsection{Coming Back to National Law - Gener- al Principles and Common Traditions}

The Court's reasoning in a variety of cases illustrates its firm belief in the supremacy of EU law over national law:

"[R]ecourse to the legal rules or concepts of national law in order to judge the validity of measures adopted by the institutions of the community would have an adverse effect on the uniformity and efficacy of community law. The validity of such measures can only be judged in the light of community law. In fact, the law stemming from the Treaty, an independent source of law, cannot because

46 Mr. Justice John L. Murray, 'Methods of Interpretation - Comparative Law Method', in, Actes du colloque pour le cinquantième anniversaire des Traités de Rome, L'influence du droit national et de la jurisprudence des juridictions des États membres sur l'interprétation du droit communautaire (ed. Gerichtshof der Europäischen Union), 2007, p. 40.

47 See e.g. CJEU case C-1/58, Stork \& Cie, judgment of 4 February 1959.

48 CJEU Judgment of 13 December 1979, Liselotte Hauer v. Land Rheinland-Pfalz, C-44/79, para. 21. 
of its very nature be overridden by rules of national law, however framed, without being deprived of its character as community law and without the legal basis of the community itself being called into question." 49

It is, however, of no use when issues are raised that lack an (explicit) corresponding rule in EU law, such as issues of human rights before the Lisbon Treaty and the EU Charter were adopted. And it is exactly this disregard for the lacunae in EU Law that led the Luxembourg Court to modify its comparative approach. Consciously leaving space open for human rights violations under Community law is a bold, not particularly responsible, "Daddy" approach, and is an area that has now been corrected through the adoption of the Lisbon Treaty as well as the EU Charter.

When the gap in human rights protection became apparent in the early 1970s, the Member States reacted accordingly. For instance, the German Constitutional Court, with its well-known Solange-I decision of 1974, claimed the power to control all EU-related acts with regard to the question of whether or not they violated fundamental principles of the German Constitution.

In subsequent judgments (starting with 'Internationale Handelsgesellschaften' ${ }^{50}$ ), the CJEU addressed the problem of human rights but would not turn all-out to a comparative approach based on national law, claiming that:

\footnotetext{
"Respect for fundamental rights forms an integral part of the general principles of law protected by the court of justice, the protection of such rights, whilst inspired by the constitutional traditions common to the Member States must be ensured within the framework of the structure and objectives of the community."51
}

The Luxembourg court subsequently introduced general principles as analogous guarantees inherent in Community law. ${ }^{52}$

In so doing, the CJEU returned to a comparative approach regarding the understanding of human rights in the Member States, but still preserved for itself the power to take

49 CJEU judgment of 17 December 1970, Internationale Handelsgesellschaft mbH v Einfuhr- und Vorratsstelle für Getreide und Futtermittel, C-11/70; also compare CJEU judgment of 15 July 1964, Costa v. Enel, C-6/64, p. 594; subsequent case law: Judgment of 09. March 1978, Amministrazione delle Finanze dello Stato v. Simmenthal (Simmenthal II), C-106/77, p. 644.

50 CJEU judgment of 17 December 1970, Internationale Handelsgesellschaft mbH v Einfuhr- und Vorratsstelle für Getreide und Futtermittel, C-11/70, Summary $₫ 1$ : “... the validity of a community measure or its effect within a member state cannot be affected by allegations that it runs counter to either fundamental rights as formulated by the constitutions of that state or the principles of its constitutional structure."

${ }_{51}$ CJEU judgment of 17 December 1970, Internationale Handelsgesellschaft mbH v Einfuhr- und Vorratsstelle für Getreide und Futtermittel, C-11/70, Summary $\$ 2$

52 CJEU judgment of 17 December 1970, Internationale Handelsgesellschaft mbH v Einfuhr- und Vorratsstelle für Getreide und Futtermittel, C-11/70, § 3-4; Also see CJEU C-44/79 Hauer v Land Rheinland-Pfalz. 
the ultimate decision as to what these traditions amounted to in an individual case. ${ }^{53} \mathrm{Re}$ garding human rights, the Luxembourg court - over the years - entered into a dialogue with the Member States' constitutional courts and began to take the Member States' legal systems into account.

Thus, even in the process of defining 'general principles' or 'common traditions of the Member States' law', the Luxembourg Court was able to fend off a comparative method depending entirely on national law (holding a threat of undermining the authority of EU law ${ }^{54}$ ) and instead eventually referred to the ECHR as a sort of shared position and guideline, as the Nold case from the mid-1970s shows:

\footnotetext{
"As the Court has already stated, fundamental rights form an integral part of the general principles of law, the observance of which it ensures. In safeguarding these rights, the Court is bound to draw inspiration from constitutional traditions common to the Member States, and it cannot therefore uphold measures which are incompatible with fundamental rights recognized and protected by the Constitutions of those States. Similarly, international treaties for the protection of human rights on which the Member States have collaborated or of which they are signatories, can supply guidelines which should be followed within the framework of Community law. ${ }^{35}$
}

In 1979, the CJEU went even one step further by recognizing the ECHR as a basis for interpretation of Community law, ${ }^{56}$ which, in turn, stands as the European spirit behind all constitutional traditions common to the Member States. ${ }^{57}$

\subsection{Conclusion and Perspectives}

This Luxembourg-defined link to Strasbourg case law as another twist in its 'comparative method' has been criticized however. As Corrias has said:

\footnotetext{
"Only from the perspective of the ECJ, situated in a field where general principles of EC law are called upon in order to avert the dangers to the integration process, do the constitutional traditions of the Member States appear to be 'common'. However, why then should the ECJ be the sole judge authorized to set aside EC law that contradicts fundamental rights? What threats do national courts pose to the unity and cohesion of EC law, if they assess the compatibility of EC measures from
}

Luigi Corrias, The passivity of law: competence and constitution in the European Court of Justice, (Springer 2011).p. 141.

$54 \quad$ Corrias (2011) p. 141.

55 CJEU judgment of 14 May 1974, J. Nold Kohlen- und Baustoffhandlung v. Commission of the European Communities, C 4/73, $\$ 13$.

56 CASE 44/79 Hauer (prelimimary ruling).

57 CJEU judgment of 13 December 1979, Hauer v Land Rheinland-Pfalz, C-44/79, $\$ 14-15$. For an overview of the observation of human rights norms in CJEU cases, see Silvia Allegrezza, The Interaction between the ECJ and the ECtHR with Respect to the Protection of Procedural Safeguards after Lisbon: the Accession of the EU to the ECHR, in Toward a Prosecutor for the European Union - a Comparative Analysis (ed. Katalin Ligeti), Hart Publishing 2013, pp. 905-944, 908 ff. 
'common traditions'? (...) Here is the circularity in the reasoning of the Court: The commonness of constitutional traditions is only to be found by the ECJ, if it presupposes a commonness of traditions. The ECJ acts like a magician pulling from its hat a rabbit that it has first put there itself.'58

Furthermore, the ECHR-based interpretation of Community law and the indirect protection of human rights therein could not only lead to a conflict of competencies with the ECtHR, but might not be an adequate approach at all as we will see in the conclusion.

With regard to the different mandates of the European Courts, as is well known, the CJEU held in the Kremzow ${ }^{59}$ decision that it will only consider complaints regarding violations of human rights if these rights were infringed by Community law, ${ }^{60}$ whereas the Strasbourg Court refrains from reviewing EU action based on the doctrine of 'equivalent protection', basically claiming that as long as the protection offered by the EU in a certain case is not dysfunctional, and thus not manifestly deficient, it will refrain from intervention. ${ }^{6}$

\section{Comparing the Approaches}

In conclusion, what are the differences in the comparative methods and what is the common ground of the two European Courts - and where will it eventually lead?

\subsection{Differences}

Having looked at the approaches of the two courts in closer detail, we have seen quite a few disparities. Although both courts relate to the national level, they do so differently.

When applying a comparative method, the Strasbourg Court looks for a common denominator, whereas the Luxembourg Court seeks a synthesis of national laws in order to establish the appropriate solution for EU law, and therefore only seeks the spirit in national law where necessary.

The reason behind such differences lies first and foremost within the distinct situations and objectives of the Strasburg Court on the one hand and of the Luxembourg Court on the other.

The Strasbourg Court "only" oversees national actions and court judgments with respect to human rights - its objective is human rights protection on a case-by-case basis. This is a rather narrow field with strict limits: Every time the ECtHR comes into play, there is the threat of a sanction and the threat of rejection of a national court's decision (since applicants only have access to the Court after their claim has been reviewed by first instance courts of the respective national system). In some ways, the Strasbourg Court

\footnotetext{
$58 \quad$ Corrias (2011) p. 143.

59 CJEU judgment of 29 May 1997, Kremzow v. Austria, C-299/95.

60 CJEU C-185/95 Baustahlgewebe GmbH v. Commission, $₫ 29$.

$61 \quad$ ECtHR Bosphorus Airlines v. Ireland, para 166.
} 
has the traditional, everyday 'Mommy' job of letting the children make mistakes (in order to gain experience) and - if necessary - to scold them repeatedly.

The Luxembourg Court as the 'motor of European integration' has a broader and more complex relationship with States and their courts. It finds itself in the same situation as the Strasbourg Court when it must decide whether a national court's decision runs against EU law or when asked to rule against a State in proceedings because of a Treaty violation. But it is not restricted to a 'No No' approach in a case-by-case scenario as it has the possibility to build a vision when giving its opinion beforehand in a preliminary ruling (or even in an opinion, based on Art. 218 para 1 TFEU). The latter-mentioned procedure not only allows for more coherent EU law by correcting poor behaviour, but also allows the CJEU to give shelter to national courts, which sometimes forward cases to Luxembourg when they have reached a deadlock at the national level or when the issues are too politically sensitive to be decided by them alone. Most of the landmark decisions of the CJEU are indeed preliminary rulings. From a historical, conventional perspective, this rather audacious role may be deemed a traditional 'Daddy' job, handing down clear guidelines to the children when confronted with difficult decisions and new problems. However, this approach relies on an ultimate power to decide, leaving no room for any individualistic interpretation of directives or the development of independent decision-making. Thus, the approach may sometimes provoke an argument with or even act of defiance by the "children".

\subsection{Common Ground}

Yet, the initial appearance of vast differences could be deceptive because both courts indeed share a common ground and might actually be moving closer together, as is foreseen in Article 6 paragraphs 2 and 3 of the EU Treaty. ${ }^{62}$

One of the central similarities is that both depend on national courts to enforce their judgments, and in the long run, they must win their support. A comparative method, which takes national law into account, is thus an attractive option: both courts search for the common European standard in the domestic laws, but they eventually turn to international legal frameworks if no answers can be found at the national level. ${ }^{63}$ Moreover, both do so in a rather vague, sometimes inconsistent comparative manner. ${ }^{64}$ This is, however, not surprising given the gaps and flaws in the general theory of comparative

62 For a closer assessment of the accession of the EU to the ECHR, see Silvia Allegrezza, The Interaction between the ECJ and the ECtHR with Respect to the Protection of Procedural Safeguards after Lisbon: the Accession of the EU to the ECHR, in Toward a Prosecutor for the European Union - a Comparative Analysis (ed. Katalin Ligeti), Hart Publishing 2013, pp. 905-944, 918 ff.

63 Ambrus, p. 363 with further references to the case law.

64 Ambrus, pp. 368 - 370 with further references to dissenting opinions, case law and scholars (key criticisms: the comparison is too superficial, and it leads to diverging or conflicting interpretations due to a methodologically incorrect comparison); Dialogue between Judges, pp. 15 and 18. 
law and given the fact that the courts' judges come from various European countries, and their solutions therefore mirror their distinct legal backgrounds. ${ }^{65}$

\section{6 "Because Mommy said so..." - In Conclusion}

In conclusion, the initial scenario recurs where we can draw a parallel with the notion of 'playing house'. Very often, the family situation is also about sharing burdens as well as about who holds the power. Or, put differently, it is about who sets the rules in the end, with or without applying a traditional stereotypical view of a well-set family.

Always, an important question for parents is: Who takes responsibility? Whereas an important question for children is: Who is more assertive - Mommy or Daddy?

Today, both European Courts take responsibility, albeit in different areas. Indeed, Article 6 paragraph 3 of the EU Treaty opens up the field for a new sharing of burdens. Both courts hold a strong position in their field. However, the CJEU appears to be the less compromising and thus more successful at first glance.

The CJEU is the highest court in the EU, with a mandate to align national law to EU law where necessary. With the European Union's competences growing ever wider and deeper, so does the Luxembourg Court's competence: In its own area, it basically has the power to rule. This finding is supported by its initial approach of not seriously taking national law into account when making a decision, and in doing so, the CJEU has put national constitutional or high courts under considerable pressure. ${ }^{66}$

It is therefore interesting, yet rather dangerous in the long run - given the development of an EU area of Freedom, Security and Justice - that the Luxembourg Court resorts to the case law of the Strasbourg Court in all human rights issues. The latter is - as we have heard before - about a minimum standard, a common denominator only, and not a European vision. ${ }^{67}$

The Luxembourg Court's reliance on Strasbourg case law might initially increase the acceptance of the CJEU's judgments in the Member States, but on the other hand, it may - despite being a time-consuming and possibly painful development - get in the way of its own principles and interpretations.

The current approach of the Luxembourg Court to decisions by the Strasbourg Court is an easy alternative to developing its own human rights standards, shifting part of its responsibility to the ECtHR. This reminds us of the situation confronted by families all over the world every night: Daddy wants the children to go to bed, and when confronted

${ }^{65}$ Höland, Wirkungen der Rechtsprechung des Europäischen Gerichtshofs für Menschenrechte im deutschen Recht, p. 96.

${ }_{66}$ In 1964, the CJEU declared the supremacy of European law over national law in the Costa v. Enel case (15.07.1964), after having imposed the principle of direct effect a year earlier (Van Gend en Loos, 05.02.1963).

67 CJEU C-185/95 Baustahlgewebe GmbH v. Commission, $\$ 20-21$. 
Gless and Martin

with the whining children, he chooses the easy way out - "You have to go to bed because Mommy said so!" 